\title{
Swafoto Kelompok Sebagai Task Design Permutasi pada Pembelajaran Jarak Jauh
}

\author{
Refayafis Naibaho ${ }^{1}$, Kimura Patar Tamba ${ }^{2}$, Yanuar Rahmat Ndraha ${ }^{3}$ \\ ${ }^{1}$ Sekolah Kristen Makedonia, Ngabang, Kalimantan Barat \\ ${ }^{2,3}$ Program Studi Pendidikan Matematika, Fakultas Ilmu Pendidikan, Universitas Pelita Harapan, \\ Refayafis.naibaho@sma.makedonia.sch.id
}

\begin{abstract}
Task design or task design is an important component in encouraging the learning process of mathematics. The purpose of this study was to develop a task design for learning the topic of permutations. This study involved 80 high school students in Ngabang, West Kalimantan from January 1 to March 5, 2021. This study used a didactic engineering methodology consisting of four stages, namely 1) preliminary analysis, (2) design and a priori analysis, (3) implementation, observation and data collection, and (4) a posteriori analysis. Task design is prepared using the framework of the Didactic Situation Theory. At each stage, especially the fourth stage, the data were analyzed descriptively. The results showed that for the permutation material, a task design could be made in the form of a group selfie. The group selfie is a fundamental situation in the design task which is constructed with the framework of the Didactic Situation Theory and according to the context of the students. This task design is also able to encourage students to construct their knowledge through group selfie problems. In the context of distance learning, during this pandemic, group selfies are a form of contextual task design and encourage students to be actively involved because they are personal. The results of this study also show the potential and use of Didactic Situation Theory as a task design framework on the topic of permutations in high school.
\end{abstract}

Keywords: Permutation, Task Design, Theory of Didactics Situation

\begin{abstract}
Abstrak
Task design atau desain tugas merupakan komponen penting dalam mendorong terjadinya proses belajar matematika. Tujuan penelitian ini adalah untuk menyusun task design pembelajaran topik permutasi. Penelitian ini melibatkan 80 siswa Sekolah Menengah Atas di Ngabang, Kalimantan Barat pada tanggal 1 Januari sampai 5 Maret 2021. Penelitian ini menggunakan metodologi didactic engineering yang terdiri dari empat tahap yaitu 1) preliminary analysis, (2) design and a priori analysis, (3) implementation, observation, and data collection, dan (4) a posteriori analysis. Task design disusun dengan menggunakan kerangka Teori Situasi Didaktis. Pada setiap tahap, khususnya tahap keempat, data dianalisis secara deskriptif. Hasil penelitian menunjukkan bahwa untuk materi permutasi dapat dibuat task design berupa swafoto kelompok. Swafoto kelompok merupakan fundamental situation dalam task design yang dikonstruksi dengan kerangka Teori Situasi Didaktis dan sesuai dengan konteks siswa. Task design ini juga mampu mendorong siswa mengkonstruksi pengetahuannya melalui permasalahan swafoto kelompok. Dalam konteks pembelajaran jarak jauh, pada masa pandemi ini, swafoto kelompok merupakan bentuk task design yang kontekstual dan mendorong siswa terlibat aktif karena sifatnya personal. Hasil penelitian ini juga menunjukkan potensi dan penggunaan Teori Situasi Didaktis sebagai kerangka task design pada topik permutasi di Sekolah Menengah Atas.
\end{abstract}

Kata kunci: Permutasi, Desain Didaktis, Teori Situasi Didaktis.

Copyright (c) 2021 Refayafis Naibaho, Kimura Patar Tamba, Yanuar Rahmat Ndraha

$\triangle$ Corresponding author: Kimura Patar Tamba

Email Address: kimura.tamba@uph.edu (Curug, Tangerang)

Received 29 July 2021, Accepted 06 December 2021, Published 27 December 2021

\section{PENDAHULUAN}

Permutasi merupakan salah satu topik esensial dalam matematika sekolah (Kemendikbud, 2016; NCTM, 2000, 2014). Oleh karena itu, siswa harus memiliki pemahaman dan kemampuan matematis yang baik dalam topik permutasi. Namun dalam situasi normal saja (sebelum pandemi), berbagai penelitian sudah menunjukkan bahwa siswa mengalami hambatan, kesalahan bahkan 
miskonsepsi akan topik permutasi (Chotikarn et al., 2021; Pittman \& Herman, 2015; Sukoriyanto et al., 2016). Sementara pada masa pandemi, penelitian juga menunjukkan hasil yang sama bahwa siswa mengalami kesulitan dalam memahami topik permutasi (Biladina et al., 2021). Untuk itu, perlu dirancang suatu pembelajaran yang dapat mengembangkan pemahaman dan kemampuan matematis siswa dalam topik permutasi khususnya yang sesuai dengan konteks pandemi saat ini. Salah satu bagian penting dalam pembelajaran adalah desain tugas.

Task design (desain tugas) merupakan bagian penting dalam pembelajaran. Aktivitas pembelajaran matematika diinisiasi oleh task (tugas-tugas) yang diberikan pada siswa (Watson \& Ohtani, 2015). Dengan demikian, guru penting mengkonstruksi desain tugas yang baik sehingga mendorong siswa bermatematika. Task akan memunculkan aktivitas yang memberikan kesempatan untuk berjumpa dengan konsep, ide dan strategi matematis dan juga digunakan untuk mengembangkan kemampuan berpikir matematis dan inkuiri (Leung \& Baccaglini-Frank, 2017; Margolinas et al., 2013). Dalam hal ini, tugas (task) didefenisikan sebagai tugas atau aktivitas yang diajukan oleh guru untuk dilakukan siswa baik dalam bentuk permasalahan-permasalahan, aktivitas didaktis, proyek, dll (Clarke et al., 2009; Leung \& Baccaglini-Frank, 2017; Margolinas et al., 2013; Sullivan et al., 2013; Watson \& Ohtani, 2015).

Dalam konteks pandemi ini, pembelajaran dilakukan secara jarak jauh. Dalam pembelajaran jarak jauh faktor penting yang menjadi kunci terlaksananya pembelajaran yang baik adalah kemandirian siswa untuk belajar. Kemandirian penting karena siswa akan melakukan pembelajaran tanpa pengawasan guru dan teman-temannya. Selain kemandirian, karakteristik penting lain dalam pembelajaran jarak jauh adalah kontekstual. Kontekstual berarti tugas-tugas dan aktivitas pembelajaran harus berhubungan langsung dan erat dengan kehidupan anak (Engelbrecht et al., 2020).

Faktor-faktor kunci dalam pembelajaran jarak jauh ini harus menjadi dasar dalam penyusunan task design. Menurut Souto dan Borba (2018) dalam pembelajaran jarak jauh dalam jaringan saat ini, internet harus menjadi sumber utama informasi. Implikasinya, aktivitas pembelajaran harus lebih memberikan kesempatan siswa melakukan tugas-tugas kontekstual, dibanding hanya mentransmisikan pengetahuan karena siswa sudah dapat dengan mudah mendapatkan informasi dari internet. Menurut Umar (2016) kegiatan pembelajaran yang kontekstual membuat siswa mengontruksi pengetahuannya dan merasa lebih tertantang dalam belajar matematika yang lebih rill. Tugas-tugas kontekstual ini akan mendorong siswa terlibat aktif membangun pemahamannya dibanding hanya sekadar melakukan salin-tempel dari sumber-sumber di internet (Engelbrecht et al., 2020). Oleh karena itu, tujuan penelitian ini adalah untuk menyusun desain didaktis permutasi pada pembelajaran jarak jauh.

\section{METODE}

Penelitian ini adalah penelitian kualitatif dengan menggunakan metode penelitian Didactic Engineering. Didactic Engineering (DE) merupakan metode penelitian yang mengandalkan Teori Situasi Didaktis (TDS) dan Anthropological Theory of the Didactic sebagai kerangka teorinya 
(Artigue, 2019; Godino et al., 2013; Watson \& Ohtani, 2015). Metodologi DE ini terdiri dari empat tahapan yaitu: (1) preliminary analysis, (2) design and a priori analysis, (3) implementation, observation and data collection, dan (4) a posteriori analysis (Artigue, 2019; Godino et al., 2013; Watson \& Ohtani, 2015). Pada penelitian ini, kerangka yang akan digunakan adalah TDS, oleh karena itu keempat tahapan akan menyesuaikan dengan kerangka TDS tersebut. Berikut dijelaskan empat tahapan (prosedur) penelitian DE ini dengan kerangkan TDS.

Tahap preliminary analysis mencakup analisis epistemologis dari konten matematika yang akan diajarkan (dalam hal ini permutasi), analisis kondisi dan hambatan yang mungkin terjadi di sekolah (baik kurikulum, sosial, dll). Selain itu, analisis hambatan epistemologis, didaktis dan ontologis juga menjadi salah satu bagian dari tahap ini. Semua analisis pada tahap ini dilakukan melalui studi literatur.

Pada tahap design and a priori analysis akan disusun suatu task design berdasarkan hasil analisis preliminary analysis. Pada tahap ini model epistemologi dari permutasi dikonstruksi berdasarkan situasi fundamental yang mencakup situasi aksi, formulasi dan validasi.

Tahap implementation, observation, and data collection mencakup implementasi task design dalam pembelajaran dan sekaligus mengumpulkan data mengenai respon siswa atas situasi tersebut. Pengumpulan data dilakukan secara kualitatif dengan mengumpulkan hasil-hasil pekerjaan, kesulitan dan respons siswa atas task design. Sementara pada tahap a posteriori analysis, akan dilakukan analisis atas data yang dikumpulkan bersamaan dengan penerapan task design. Data ini digunakan untuk menguji dan memperbaiki task design.

Validasi dalam penelitian ini bersifat internal yaitu berdasarkan perbandingan (konfrontasi) antara analisis apriori dengan analisis posteriori (Godino et al., 2013). Oleh karena itu, validasi task-design dilakukan dengan perbandingan antara analisis apriori dengan analisis posteriori.

\section{Tempat dan Waktu Penelitian}

Penelitian ini dilakukan pada salah satu Sekolah Menengah Atas di Ngabang, Kalimantan Barat pada tanggal 11 Januari sampai dengan 5 Maret 2021. Terdapat 80 orang siswa yang terlibat dalam penerapan desain didaktis ini pada pembelajaran permutasi. Desain didaktis ini disusun untuk tiga kali pertemuan dengan masing-masing pertemuan selama 135 menit. Pembelajaran dilakukan secara jarak jauh (dalam dan luar jaringan).

\section{Metode Pengumpulan Data}

Metode pengumpulan data menggunakan 4 tahap pada DE yaitu tahap 1 preliminary analysis, tahap 2 design and a priori analysis, tahap 3 implementation, observation, and data collection, dan tahap 4 a posteriori analysis. Pada tahap 1 dilakukan analisis konten dan hambatan. Dalam hal ini analisis dilakukan dengan mempertimbangkan berbagai jenis fenomena didaktis hipotetis yang ada baik di buku-buku teks, penelitian maupun kurikulum (Artigue, 2019; Watson \& Ohtani, 2015). Pada tahap ini juga dilakukan analisis epistemologi mengenai permutasi, fenomena didaktis hipotetis yang ada mengenai permutasi, dan hambatan belajar (epistemologis, didaktis dan ontologis). 
Pada tahap 2 dilakukan berdasarkan hasil dari tahap 1. Untuk mengkonstruksi situasi ini, pertamatama dikonstruksi dan ditentukan situasi fundamental berupa aktivitas, permasalahan ataupun tugastugas lain. Dimana dengan menyelesaikan atau berhadapan dengan situasi fundamental ini, siswa akan mengkonstruksi pengetahuannya mengenai permutasi. Selanjutnya pada tahap 3 data dikumpulkan melalui hasil pekerjaan siswa dan refleksi yang diberikan kepada siswa. Hasil pekerjaan siswa dikumpulkan kepada guru mata pelajaran sedangkan respon siswa dikumpulkan melalui lembar refleksi mengenai pembelajaran dengan task design. Pertanyaan-pertanyaan dalam lembar refleksi tersebut adalah (1) menurutmu apa saja kelebihan dan kekurangan aktivitas ini, dan (2) apakah aktivitas ini menambah pemahamanmu? Terakhir tahap 4 dilakukan analisis data yang dikumpulkan pada saat task design ini dilaksanakan. Data hasil pekerjaan siswa akan dianalisis secara kualitatif deskriptif. Sementara data dari lembar refleksi dianalisis dengan melakukan koding. Hasil analisis ini kemudian digunakan untuk melakukan perbaikan atas desain didaktis awal.

\section{HASIL DAN DISKUSI}

\section{Preliminary Analysis}

Bagian ini memaparkan tiga bagian besar preliminary analysis. Pertama, analisis epistemologi (termasuk didalamnya analisis hambatan epistemologi dan situasi fundamental) mengenai topik permutasi. Hasil analisis menunjukkan siswa menggunakan konsep aturan perkalian dalam memahami permutasi (Pittman \& Herman, 2015). Artinya siswa memahami permutasi sebagai aturan perkalian. Namun sebenarnya permutasi tidak sekadar atau sesederhana aturan perkalian. Pada konteks permutasi. Sementara mengenai hambatan epistemologis terlihat bahwa siswa sering melihat melakukan generalisasi konsep permutasi pada kombinasi dan sebaliknya (Biladina et al., 2021; Chotikarn et al., 2021; Sukoriyanto et al., 2016). Dalam kasus tertentu, permasalahan permutasi memang dapat diselesaikan dengan konsep kombinasi atau sebaliknya. Untuk itu, pada task desain yang akan disusun harus mempertimbangkan hambatan epistemologis ini. Kedua, analisis institutional menunjukkan bahwa pada kondisi pembelajaran jarak jauh, siswa memerlukan aktivitas pembelajaran yang dekat dengan kegiatan sehari-hari. Ketika pembelajaran berlangsung di sekolah siswa bisa mengerjakan aktivitas tanpa ada perantara media sosial, namun dalam kondisi sekarang ini siswa lebih banyak berinteraksi di media sosial sehingga, aktivitas yang dirancang juga memanfaatkan media sosial. Adapun standar kompetensi yang harus dikuasi oleh siswa mengenai permutasi adalah menyelesaikan masalah kontekstual yang berkaitan dengan kaidah pencacahan (aturan penjumlahan, aturan perkalian, permutasi, dan kombinasi). Kompetensi ini berkaitan dengan materi sebelumnya tentang kaidah pencacahan aturan penjumlahan dan perkalian. Dengan pengetahuan ini maka siswa diharapkan dapat melihat pola. Dengan kemampuan melihat pola ini kemudian diharapkan siswa mampu memahami konsep awal dari permutasi.

Ketiga, analisis fenomena didaktik. Hasil analisis fenomena didaktik diperoleh dengan melakukan survey dan analisis pada buku teks maupun penelitian terdahulu. Ada dua buku teks yang 
dianalisis yaitu buku teks yang dikeluarkan Kemendikbud pada tahun 2018 untuk siswa kelas XII dan buku Matematika SMA/MA tahun 2014. Pada buku teks yang pertama, permutasi diperkenalkan dengan cara menggunakan media kartu remi. Pada buku teks kedua permutasi dijelaskan melalui definisi dan contoh soal. Sementara dari penelitian terdahulu ditemukan beberapa pendekatan yang digunakan dalam belajar permutasi. Pertama, metode play-way yaitu metode yang melibatkan tindakan melihat, mendengar, mengatakan dan melakukan, yang membuatnya lebih mudah untuk diingat (Makinde, 2014). Asumsi yang mendasari penggunaan metode ini adalah permutasi membutuhkan kemampuan mengingat yang baik. Kedua, pendekatan dengan konteks pola nada pada musik (Fenton, 2009). Pendekatan ini menggunakan clapping music, dimana siswa didorong melihat konsep permutasi dari banyaknya variasi nada. Ketiga, pendekatan photograph (Szydlik, 2000). Pendekatan ini memperkenalkan konsep permutasi dengan aktivitas fotografi yaitu mencari banyak pose foto yang mungkin untuk sekelompok orang secara berbaris.

\section{Design And A Priori Analysis}

Berdasarkan hasil preliminary analysis dikembangkan task design mengenai permutasi. Fundamental situation yang akan digunakan adalah aktivitas menyusun pola/formasi dimana siswa akan bisa mengkonstruksi pengetahuan bahwa permutasi dapat diselesaikan dengan aturan perkalian. Fundamental situation ini dipilih karena pengetahuan awal yang dimiliki oleh siswa adalah aturan perkalian. Selain itu, dari berbagai analisis fenoemena didaktis menunjukkan konsep permutasi itu sendiri dimulai dari penyusunan pola/formasi. Pertimbangan berikutnya pada pemilihan dan konstruksi fundamental situation ini adalah standar kompetensi dari kurikulum nasional yang digunakan di sekolah. Adapun kompetensi dasar yang digunakan pada materi ini adalah (i) menganalisis aturan pencacahan (aturan penjumlahan, aturan perkalian, permutasi, dan kombinasi) melalui masalah kontekstual, dan (ii) menyelesaikan masalah kontekstual yang berkaitan dengan kaidah pencacahan (aturan penjumlahan, aturan perkalian, permutasi, dan kombinasi). Kompetensi yang pertama disebutkan adalah siswa bisa menganalisis dari kemampuan ini kemudian diharapkan siswa bisa menyelesaikan masalah kontekstual yang berkaitan dengan materi tersebut (dalam hal ini permutasi). Pada saat Pembelajaran Jarak Jauh (PJJ) pada masa pandemi ini, siswa melakukan pembelajaran dari rumah (BDR). Artinya pembelajaran tidak dapat dilakukan secara kelompok (antar siswa), namun siswa masih dapat melakukan aktivitas dengan keluarga atau teman dekat rumahnya.

Konteks aktivitas menyusun pola/formasi yang digunakan dalam task design ini adalah swafoto kelompok (wefie). Swafoto kelompok dipilih karena konteks siswa sekarang yang gemar melakukan swafoto dan menayangkannya di akun media sosial (misalnya, instagram, facebook, dll). Dengan demikian, fundamental situation dari task design permutasi yang dikonstruksi adalah permasalahan mengenai jumlah formasi atau banyaknya pose swafoto kelompok yang bisa dibuat untuk beberapa orang. 
Tabel 1. Task Design Situasi Adidaktik dan Didaktik

\begin{tabular}{|c|c|c|}
\hline Situasi & Task Design & Penjelasan \\
\hline \multicolumn{3}{|c|}{$\begin{array}{l}\text { Situasi adidaktik } \\
\end{array}$} \\
\hline Aksi & $\begin{array}{l}\text { Lakukan kegiatan ini sebanyak } 3 \\
\text { kali. } \\
\text { Ajaklah teman atau anggota } \\
\text { keluargamu pertama (sebanyak } 1 \\
\text { orang), kedua (sebanyak } 2 \\
\text { orang), dan ketiga (sebanyak } 3 \\
\text { orang) lalu kamu dan semua } \\
\text { semua temanmu akan berfoto, } \\
\text { tentukan banyaknya cara berfoto } \\
\text { jika setiap kali pemotretan } \\
\text { (pertama, kedua, dan ketiga) } \\
\text { hanya boleh diisi satu, dua, dan } \\
\text { tiga orang saja. }\end{array}$ & $\begin{array}{l}\text { Situasi ini disusun agar siswa dapat } \\
\text { mengingat dan menggunakan pemahaman } \\
\text { sebelumnya tentang aturan penjumlahan } \\
\text { dan perkalian, untuk menyelesaikan } \\
\text { masalah permutasi tanpa memberitahu } \\
\text { terlebih dahulu bahwa pada konteks ini, } \\
\text { siswa sedang menyelesaikan } \\
\text { permasalahan permutasi. Situasi ini } \\
\text { disusun dengan mengarahkan siswa untuk } \\
\text { melakukan sebuah kegiatan nyata dan } \\
\text { mengambil kesimpulan dari kegiatan itu. }\end{array}$ \\
\hline Formulasi & $\begin{array}{l}\text { Berdasarkan hasil } 3 \text { kali berfoto } \\
\text { dengan ketentuan yang sudah } \\
\text { disebutkan. Buatlah kembali ke } \\
\text { dalam bentuk diagram pohon di } \\
\text { selembar kertas. }\end{array}$ & $\begin{array}{l}\text { Situasi ini bertujuan untuk mendorong } \\
\text { siswa melakukan formulasi atas } \\
\text { permasalahan dan aktivitas pada situasi } \\
\text { aksi. Aktivitas membuat diagram } \\
\text { merupakan situasi yang disusun agar } \\
\text { siswa memformulasikan pengetahuannya. }\end{array}$ \\
\hline Validasi & $\begin{array}{l}\text { Gabungkan seluruh hasil foto } \\
\text { (nomor 1, 2, dan 3) serta hasil } \\
\text { dari diagram yang telah kamu } \\
\text { kerjakan (Kamu bisa kreasikan } \\
\text { sendiri seperti: gabung foto, } \\
\text { poster, dsb). Lalu kumpulkan } \\
\text { hasil akhirnya melalui video atau } \\
\text { foto ke IG feed atau story } \\
\text { dengan menandai akun } \\
\text { (fistanaibaho). }\end{array}$ & $\begin{array}{l}\text { Dengan situasi ini, siswa juga dapat } \\
\text { mepresentasikan hasilnya dengan } \\
\text { membuat sebuah video. Tujuan situasi ini } \\
\text { adalah agar siswa dapat melakukan } \\
\text { validasi atas pengetahuan yang telah } \\
\text { dikonstruksi pada situasi formulasi. } \\
\text { Validasi dilakukan dengan melihat hasil } \\
\text { pekerjaan temannya di media sosial } \\
\text { instagram (IG). Selain itu, situasi ini juga } \\
\text { memberikan ruang apresiasi atas } \\
\text { pengetahuan mereka dengan sebuah karya } \\
\text { yang merupakan hasil dari usaha siswa } \\
\text { sendiri. Hasilnya kemudian diposting } \\
\text { melalui media sosial, hal ini sangat } \\
\text { kontekstual di masa pandemi dengan } \\
\text { memanfaatkan perkembangan media } \\
\text { sosial untuk belajar. }\end{array}$ \\
\hline \multicolumn{3}{|c|}{$\begin{array}{c}\text { Situasi didaktik } \\
\end{array}$} \\
\hline Institusionalisasi & $\begin{array}{l}\text { Siswa diberikan modul yang } \\
\text { dikirim oleh guru melalui google } \\
\text { classroom. Guru mengobservasi } \\
\text { pelaksanaan situasi ini } \\
\text { melalui tengan } \\
\text { menanyakan proses atau } \\
\text { hambatan yang muncul dalam } \\
\text { aktivitas ini. }\end{array}$ & $\begin{array}{l}\text { Situasi ini bertujuan untuk memberikan } \\
\text { klarifikasi atas pengetahuan yang telah } \\
\text { dikonstruksi oleh siswa. Oleh karena itu } \\
\text { modul ini menjadi semacam umpan balik } \\
\text { atas pekerjaan siswa. Hal ini bertujuan } \\
\text { untuk membawa pengetahuan matematika } \\
\text { siswa menjadi pengetahuan matematika } \\
\text { formal mengenai permutasi. }\end{array}$ \\
\hline
\end{tabular}

\section{Implementation, Observation, and Data Collection}

Berikut ini dipaparkan pelaksanaan pembelajaran dengan task design yang telah disusun dan respon siswa dalam setiap situasi tersebut. Pertama, pada situasi aksi siswa melakukan aktivitas 
swafoto kelompok. Guru mengobservasi pelaksanaan aktivitas ini melalui telegram kelas. Guru akan menanyakan proses atau hambatan yang muncul dalam aktivitas ini. Pada aktivitas ini, siswamenghasilkan berbagai pose swafoto kelompok. Berikut contoh hasil swafoto kelompok yang dilakukan (gambar 1).
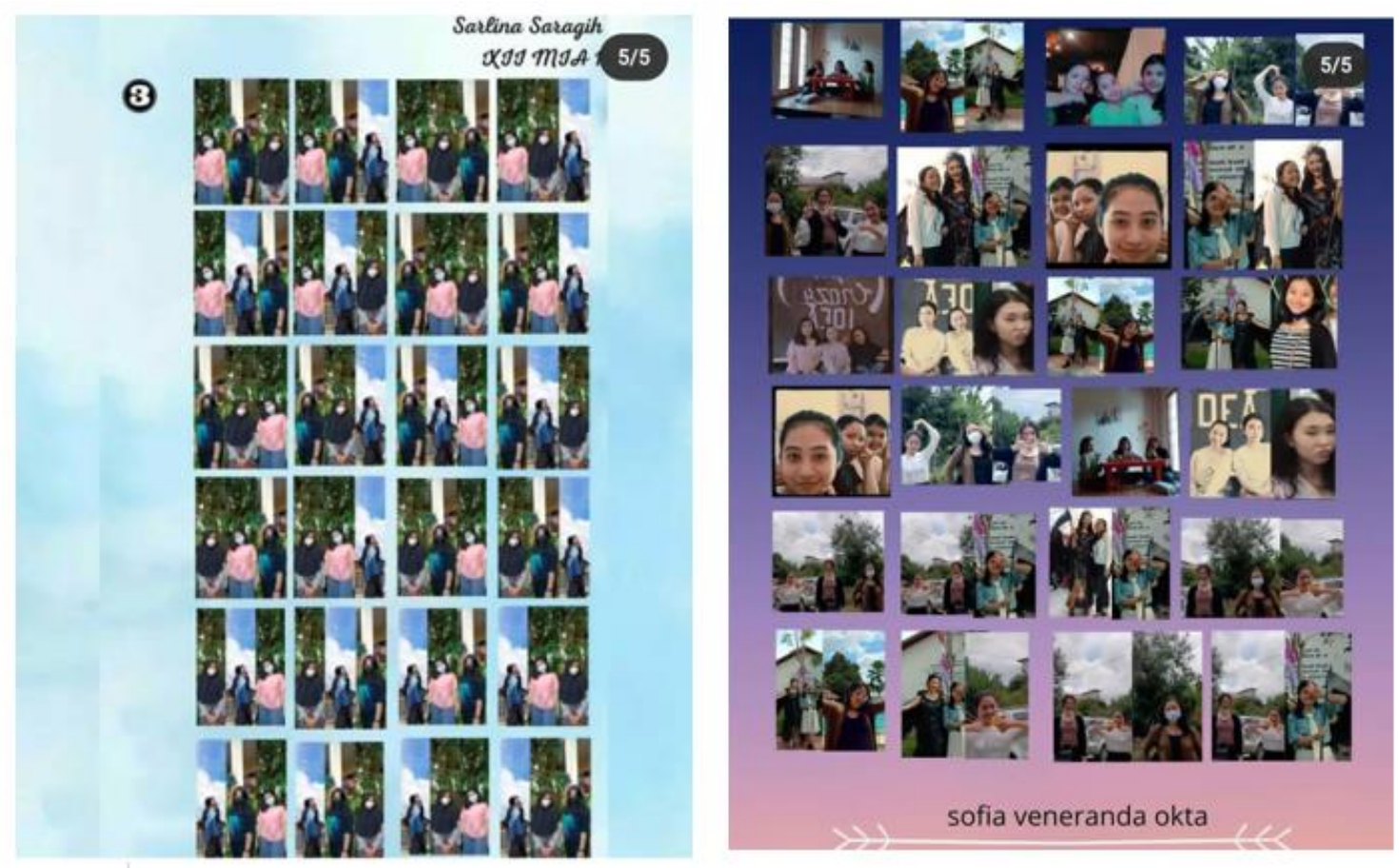

Gambar 1. Contoh pekerjaan siswa pada situasi aksi

Hasil observasi guru atas aktivitas ini menunjukkan bahwa pada situasi aksi, aktivitas yang diberikan mampu menarik kreativitas siswa karena, untuk beberapa siswa ada yang kesulitan mencari teman untuk diajak berfoto, ada juga beberapa dari siswa pria yang tidak terlalu tertarik untuk melakukan foto. Namun, permasalahan di atas dapat diatasi dengan cara siswa mengedit foto yang sudah ada menjadi sebuah susunan seperti yang diinstruksikan. Hasil lainnya menunjukkan bahwa dengan melakukan aktivitas berfoto, siswa lebih memahami konteks pelajaran yang mereka pelajari dengan kehidupan sehari-hari.

Hasil pada situasi formulasi menunjukkan bahwa siswa memahami cara membuat diagram dari hasil foto yang sudah mereka lakukan sebelumnya. Siswa membuat diagram kemungkinan pose swafoto yang mereka lakukan (Gambar 2). Berdasarkan diagram ini, siswa kemudian mengkonstruksi formula matematika untuk menentukan jumlah pose swafoto yang mungkin. Artinya, siswa mengkonstruksi pengetahuan matematikanya mengenai aturan permutasi dengan menggunakan pemahamannya akan aktivitas pada situasi aksi. 


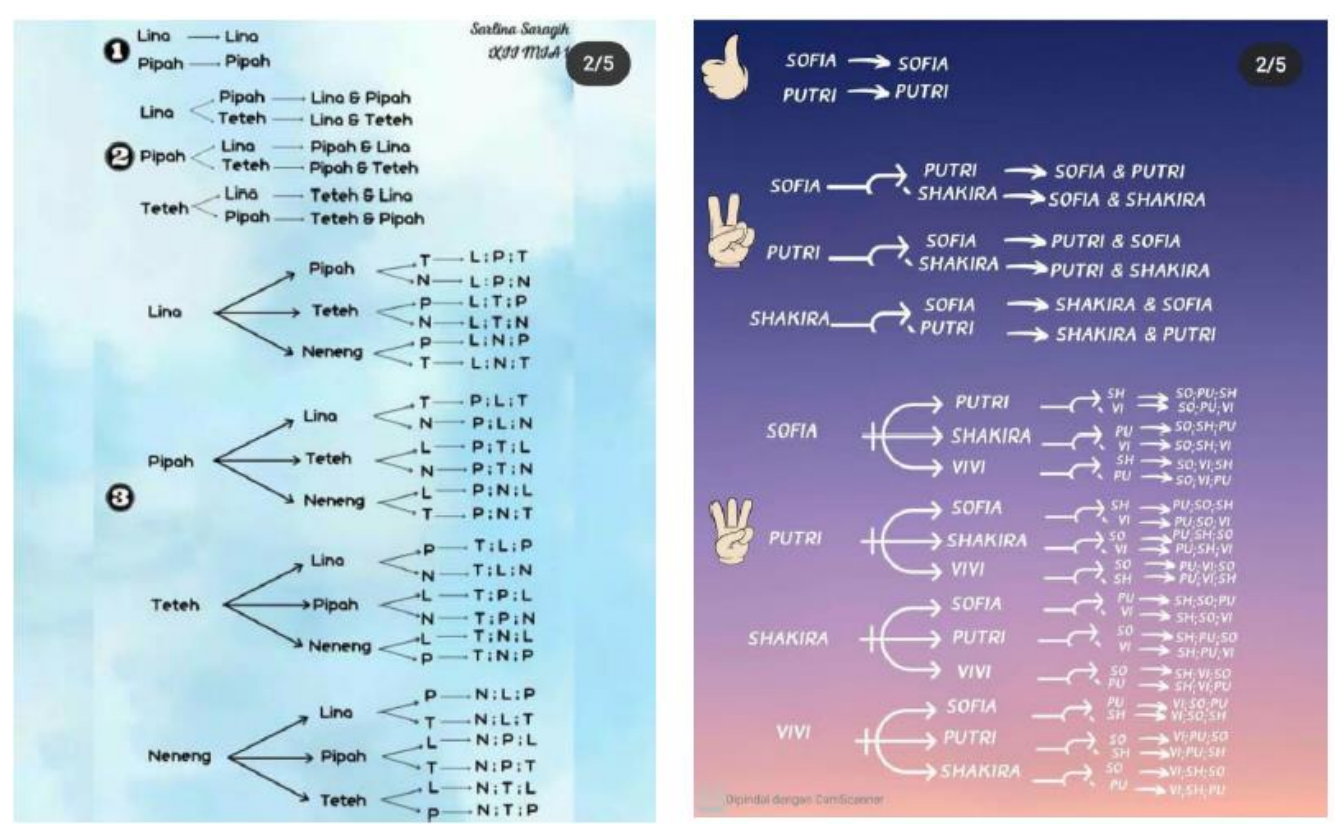

Gambar 2. Contoh hasil formulasi siswa atas permasalahan swafoto kelompok

Pada situasi validasi, siswa mengkomunikasikan hasil pekerjaannya (konstruksi pengetahuannya) pada situasi aksi dan formulasi melalui video. Video ini diunggah pada media sosial ataupun link onedrive yang disediakan. Siswa melakukan validasi dengan melihat kembali pekerjaannya saat memproduksi video dan menonton video penjelasan teman. Situasi validasi ini sangat mungkin terjadi karena penyajian setiap siswa berbeda sehingga memperkaya pemahaman mereka akan aturan permutasi.

Situasi institusionalisasi dilakukan oleh guru dengan memberikan modul. Modul ini disusun berdasarkan hasil pekerjaan siswa pada situasi adidaktik (aksi, formulasi dan validasi). Modul ini dikirim oleh guru melalui google classroom. Guru mengobservasi pelaksanaan situasi ini dengan melalui telegram dengan menanyakan proses atau hambatan yang muncul dalam aktivitas ini. Hasil institusionalisasi ini terjadi dengan baik dimana siswa mampu mentransformasi pengetahuan matematika-nya pada situasi adidaktik menjadi pengetahuan matematika formal. Hal ini terlihat pada hasil pekerjaan siswa atas permasalahan yang diberikan pada situasi institusionalisasi (Gambar 3). Hasil pekerjaan ini (Gambar 3) menunjukkan siswa menyelesaikan permasalahan permutasi dengan rumus.

Hasil ini juga diperkuat dari respon siswa terhadap pelaksanaan situasi ini. Respon yang diberikan sesuai dengan harapan peneliti ketika merancang aktivitas ini. Siswa menyatakan bahwa kelebihan dari aktivitas ini adalah menyajikan permasalahan yang kontekstual sehingga mereka dapat memahami konsep permutasi. Siswa juga belajar bagaimana menyajikan hasilnya dalam bentuk yang sesuai dengan kreativitas mereka. Beberapa dari siswa menyatakan bahwa pada awalnya sulit memahami instruksi dari aktivitas namun, ketika sudah mencoba siswa bisa memahami tujuannya. Kendala yang umumnya terjadi adalah siswa kesulitan mencari teman untuk diajak berfoto. 
Tabel 2. Deskripsi respon siswa atas task design

\begin{tabular}{|l|l|}
\hline \multicolumn{1}{|c|}{ Kode } & \multicolumn{1}{|c|}{ Deskripsi } \\
\hline $\begin{array}{l}\text { Permasalahan } \\
\text { kontekstual }\end{array}$ & $\begin{array}{l}\text { Siswa menyatakan bahwa kelebihan dari aktivitas ini adalah } \\
\text { menyajikan permasalahan yang kontekstual sehingga mereka dapat } \\
\text { memahami konsep permutasi. }\end{array}$ \\
\hline Mendorong kreativitas & $\begin{array}{l}\text { Beberapa dari siswa menyatakan bahwa pada awalnya sulit } \\
\text { memahami instruksi dari aktivitas namun, ketika sudah mencoba } \\
\text { siswa bisa memahami tujuannya. }\end{array}$ \\
\hline
\end{tabular}

Hasil di atas menunjukkan beberapa temuan penelitian. Pertama, fundamental situation berbentuk masalah yang disimulasikan (dalam hal ini swafoto kelompok) dan sesuai dengan konteks siswa (kegemaran siswa saat ini adalah swafoto dan diunggah/tampilkan di akun media sosial menarik perhatian siswa untuk melakukan aktivitas matematika. Hasil ini konsisten dengan penelitian terdahulu yang mengungkapkan bahwa task design harus bersifat kontekstual (Huang et al., 2020; NCTM \& NCSM, 2020). Dalam konteks pembelajaran jarak jauh, pada masa pandemi ini, swafoto kelompok merupakan bentuk task design yang kontekstual dan mendorong siswa terlibat aktif karena sifatnya personal (melakukan swafoto, dan tidak bisa diwakilkan orang lain) dibanding hanya sekadar salin-tempel dari sumber-sumber di internet (Engelbrecht et al., 2020). Dengan demikian, task design ini memungkinkan interaksi secara kognitif antar siswa dan antar siswa-guru tetap terjadi meskipun fisik berjauhan (antar siswa dan antar siswa-guru) (Bakker \& Wagner, 2020). Hasil ini juga sesuai dengan penelitian terdahulu mengenai penggunaan swafoto pada topik permutasi. Penelitian Szydlik (2000) menunjukkan bahwa aktivitas pembelajaran dengan fotografi dapat membantu siswa dalam menemukan konsep permutasi. Kedua, hasil penelitian ini menunjukkan potensi dan penggunaan Teori Situasi Didaktis sebagai kerangka task design pada topik permutasi di sekolah menengah atas. Hasil ini konsisten dan semakin menguatkan berbagai penelitian terdahulu yang menggunakan Teori Situasi Didaktis dalam mengkonstruksi task design (Brousseau et al., 2014; Sulistiawati et al., 2015; Warfield, 2014).

\section{KESIMPULAN}

Berdasarkan hasil dan diskusi di atas, kesimpulan dari penelitian ini yaitu pada materi permutasi dapat dibuat sebuah task design berupa swafoto kelompok. Swafoto kelompok merupakan bentuk fundamental situation yang dapat digunakan sebagai task design pembelajaran permutasi pada sekolah menengah atas pada pembelajaran jarak jauh. Hal ini juga menunjukkan bahwa Teori Situasi Didaktis merupakan kerangka yang dapat digunakan dalam mengembangkan task design pembelajaran permutasi sekolah menengah atas pada pembelajaran jarak jauh.

Kontribusi penelitian ini pada pengembangan pengetahuan dan penelitian mengenai task design, khususnya pada topik permutasi terlihat dalam beberapa hal. Pertama, penelitian ini mengembangkan fundamental situation berupa swafoto kelompok dalam pembelajaran topik permutasi. Penelitian sebelumnya menggunakan konteks fotografi yang aktivitasnya tidak dilakukan secara langsung melainkan simulai dalam kerja (Szydlik, 2000). Swafoto kelompok sebagai 
fundamental situation pada penelitian ini merupakan aktivitas yang dilakukan secara langsung oleh siswa dan kontekstual dengan trend swafoto pada kalangan remaja saat ini. Kedua, penelitian ini memberikan gambaran mengenai konstruksi task design dengan kerangkan Teori Situasi Didaktis pada konteks pembelajaran jarak jauh. Berbagai penelitian sebelumnya belum membahas topik ini (Brousseau et al., 2014; Sulistiawati et al., 2015; Warfield, 2014).

Meskipun demikian penelitian ini terdapat keterbatasan yang perlu menjadi konsen dan topik pada penelitian lanjutan. Efektivitas penggunaan task design ini pada pengembangan pemahaman siswa belum dianalisis. Selain itu, penelitian berikutnya dapat mempertimbangkan integrasi teknologi dalam pengembangan task design. Dengan demikian, task design ini juga dapat digunakan dalam konteks pembelajaran dalam jaringan.

\section{REFERENSI}

Artigue, M. (2019). Perspectives on design research: the case of didactical. In A. B.- Ahsbahs, C. Knipping, \& N. Presmeg (Eds.), Approaches to Qualitative Research in Mathematics Education (pp. 467-496). Springer.

Bakker, A., \& Wagner, D. (2020). Pandemic: lessons for today and tomorrow? Educational Studies in Mathematics, 104(1), 1-4. https://doi.org/10.1007/s10649-020-09946-3

Biladina, S. G., Handayani, N., Yulian, M. A., Husnah, N., \& Sari, M. (2021). Analysis of student errors in combination and permutation materials with the learning system in pandemic. 4, 241245.

Brousseau, G., Brousseau, N., \& Warfield, V. (2014). Teaching Fractions through Situations: A Fundamental Experiment. Springer.

Chotikarn, N., Kanhapong, A., Tupsai, J., \& Yuenyong, C. (2021). Enhancing Grade 11 students' representation and connection in permutation and combination for their problem solving. Journal of Physics: Conference Series, 1835(1). https://doi.org/10.1088/1742$6596 / 1835 / 1 / 012023$

Clarke, B., Grevholm, B., \& Millman, R. (Eds.). (2009). Tasks in Primary Mathematics Teacher Education. Springer.

Engelbrecht, J., Llinares, S., \& Borba, M. C. (2020). Transformation of the mathematics classroom with the internet. ZDM - Mathematics Education, 52(5), 825-841. https://doi.org/10.1007/s11858-020-01176-4

Fenton, W. E. (2009). Teaching permutations through rhythm patterns. Journal of Mathematics and the Arts, 3(3), 143-146. https://doi.org/10.1080/17513470903167707

Godino, J. D., Batanero, C., Contreras, Á., Estepa, A., Lacasta, E., \& Wilhelmi, M. R. (2013). Didactic engineering as design-based research in education. Proceedings of the Eighth Congress of the European Society for Research in Mathematics Education, February, 2810-2819. http://www.erme.tu-dortmund.de/ 
Huang, R. H., Liu, D. J., Tlili, A., Yang, J. F., \& Wang, H. H. (2020). Handbook on facilitating flexible learning during educational disruption: The Chinese experience in maintaining undisrupted learning in COVID-19 Outbreak. Smart Learning Institute of Beijing Normal University UNESCO, March, 1-54. https://iite.unesco.org/news/handbook-on-facilitatingflexible-learning-during-educational-disruption/

Kemendikbud. (2016). Peraturan Menteri Pendidikan Dan Kebudayaan Nomor 21 Tahun 2016 Tentang Standar Isi Pendidikan Dasar Dan Menengah. Kemendikbud.

Leung, A. (n.d.). Exploring Techno-Pedagogic Task Design in the Mathematics Classroom Boundary object. 3-16. https://doi.org/10.1007/978-3-319-43423-0

Leung, A., \& Baccaglini-Frank, A. (Eds.). (2017). Digital Technologies in Designing Mathematics Education Tasks. Springer. https://doi.org/10.1007/978-3-319-43423-0_12

Makinde, D. O. (2014). Teaching Permutation and Combination Using Play-way Method. Journal of Education and Practice, 5(28), 209-211.

Margolinas, C., Ainley, J., \& Watson, A. (2013). Task Design in Mathematics Education. In C. Margolinas (Ed.), Proceedings of ICMI Study 22.

NCTM. (2000). Principles and Standard for School Mathematics. NCTM.

NCTM. (2014). Principles to Actions: Ensuring Mathematical Success for All. The National Council of Teachers of Mathematics, Inc.

NCTM, \& NCSM. (2020). Moving Forward: Mathematics Learning in the Era of COVID-19 (Issue June 2020). https://www.nctm.org/uploadedFiles/Research_and_Advocacy/NCTM_NCSM_ Moving_Forward.pdf

Pittman, L. C., \& Herman, G. L. (2015). Documenting students' faulty schema and misconceptions about combinations and permutations. Proceedings - Frontiers in Education Conference, FIE, 2015. https://doi.org/10.1109/FIE.2015.7344035

Sukoriyanto, S., Nusantara, T., Subanji, S., \& Chandra, T. D. (2016). Students' Errors in Solving the Permutation and Combination Problems Based on Problem Solving Steps of Polya. International Education Studies, 9(2), 11. https://doi.org/10.5539/ies.v9n2p11

Sulistiawati, S., Suryadi, D., \& Fatimah, S. (2015). Desain Didaktis Penalaran Matematis untuk Mengatasi Kesulitan Belajar Siswa SMP pada Luas dan Volume Limas. Kreano, Jurnal Matematika Kreatif-Inovatif, 6(2), 135. https://doi.org/10.15294/kreano.v6i2.4833

Sullivan, P., Clarke, D. M., \& Clarke, B. (Eds.). (2013). Teaching with Tasks for Effective Mathematics Learning. Springer.

Szydlik, J. E. (2000). Photographs and Committees: Activities That Help Students Discover Permutations and Combinations. The Mathematics Teacher, 93(2), 93-96. https://doi.org/10.5951/mt.93.2.0093

Umar, A. (2016). Pengaruh Penerapan Pendekatan Pembelajaran Kontekstual Dengan Hypnoteaching Terhadap Pemahaman Konsep Siswa. Jurnal As-Salam, 1(1), 24. 
Warfield, V. M. (2014). Invitation to Didactique. Springer.

Watson, A., \& Ohtani, M. (Eds.). (2015). Task Design In Mathematics Education. Springer. 